\title{
OPEN
}

Published online: 19 February 2020

\section{Author Correction: FTY720 Induces Autophagy-Associated Apoptosis in Human Oral Squamous Carcinoma Cells, in Part, through a Reactive Oxygen Species/Mcl-1-Dependent Mechanism}

\author{
Li-Yuan Bai, Chang-Fang Chiu, Shih-Jiuan Chiu, Po-Chen Chu \& Jing-Ru Weng \\ Correction to: Scientific Reports https://doi.org/10.1038/s41598-017-06047-9, published online 17 July 2017 \\ In the original version of this Article, there was an error in Affiliation 6 which was incorrectly listed as \\ 'Department of Marine Technology and Resources, National Sun-Yat-sen University, Kaohisung, 80424, Taiwan'. \\ The correct affiliation is listed below:
}

Department of Marine Biotechnology and Resources, National Sun-Yat-sen University, Kaohsiung, 80424, Taiwan

This error has now been corrected in the PDF and HTML versions of the Article, and in the accompanying Supplementary information file

\begin{abstract}
(c) (i) Open Access This article is licensed under a Creative Commons Attribution 4.0 International License, which permits use, sharing, adaptation, distribution and reproduction in any medium or format, as long as you give appropriate credit to the original author(s) and the source, provide a link to the Creative Commons license, and indicate if changes were made. The images or other third party material in this article are included in the article's Creative Commons license, unless indicated otherwise in a credit line to the material. If material is not included in the article's Creative Commons license and your intended use is not permitted by statutory regulation or exceeds the permitted use, you will need to obtain permission directly from the copyright holder. To view a copy of this license, visit http://creativecommons.org/licenses/by/4.0/.
\end{abstract}

(C) The Author(s) 2020 